University of Nebraska - Lincoln

DigitalCommons@University of Nebraska - Lincoln

1998

\title{
Depth of Pupation and Survival of Fruit Fly (Anastrepha spp.: Tephritidae) Pupae in a Range of Agricultural Habitats
}

P. Jane Hodgson

L John Sivinski

Gemma Quintero

Martin Aluja

Follow this and additional works at: https://digitalcommons.unl.edu/entomologyother

Part of the Entomology Commons

Hodgson, P. Jane; Sivinski, L John; Quintero, Gemma; and Aluja, Martin, "Depth of Pupation and Survival of Fruit Fly (Anastrepha spp.: Tephritidae) Pupae in a Range of Agricultural Habitats" (1998). Entomology Papers from Other Sources. 60.

https://digitalcommons.unl.edu/entomologyother/60

This Article is brought to you for free and open access by the Entomology Collections, Miscellaneous at DigitalCommons@University of Nebraska - Lincoln. It has been accepted for inclusion in Entomology Papers from Other Sources by an authorized administrator of DigitalCommons@University of Nebraska - Lincoln. 


\title{
Depth of Pupation and Survival of Fruit Fly (Anastrepha spp.: Tephritidae) Pupae in a Range of Agricultural Habitats
}

\author{
P. JANE HODGSON, ${ }^{1}$ JOHN SIVINSKI, ${ }^{2}$ GEMMA QUINTERO ${ }^{3}$ AND MARTIN ALUJA ${ }^{3}$
}

\begin{abstract}
Environ. Entomol. 27̈(6): 1310-1314 (1998)
ABSTRACT In central Veracruz State, Mexico, tephritid fruit fly pupae are commonly attacked by ants, staphylinid beetles, and other predators. Excavations in 2 sites with different soil characteristics revealed that Anastrepha spp. (Diptera: Tephritidae) larvae typically burrowed no $>2 \mathrm{~cm}$ before pupating and rarely burrowed $>5 \mathrm{~cm}$. At 4 field sites, pupae of the most commonly encountered local Anastrepha sp. (A. obliqua, ludens, and striata or fraterculus) were placed on the soil surface and at depths of 2.5 and $5 \mathrm{~cm}$ and were subsequently sampled daily for $10 \mathrm{~d}$. Pupae on the surface invariably disappeared at a greater rate than those under the surface. There was no difference in the disappearance rate of pupae buried at 2.5 and $5 \mathrm{~cm}$, suggesting that larvae would gain no benefit by pupating at depths below those encountered in nature. The rate of disappearance of the buried pupae differed considerably among the sites. At the end of the sampling period the proportion of pupae remaining ranged from 15 to $70 \%$. Differences in the species of predators present and soil characteristics may have contributed to these differences in disappearance. Pupae disappeared at the highest rate in a site with dry loose soil. It was lowest in sites with damp clay soils characterized by fine particle size and small interparticle spaces.
\end{abstract}

KEY WORDS Formicidae, Staphylinidae, Tephritidae, biological control, pupation, soil characteristics

TEPHRITID FRUTT FLIFS attack many species of fruits and vegetables and, because of quarantines, are major barriers to trade and economic development (Aluja and Liedo 1993). The importance of parasitoids as biological control agents of fruit flies has inspired numerous studies, but the role of predators has attracted relatively little attention and their contribution to population regulation is unclear (Sivinski 1996). Typically, fruit fly larvae emerge from fallen or, occasionally, ripe hanging fruits and pupate in the soil. It is when the larvae or pupae are in or on the soil that the insects are presumably most vulnerable to predation, and ants are among the most frequently noted predators of immature tephritids (e.g., Silvestri 1914). Pemberton and Willard (1918) estimated that Pheidole megacephala (F.) consumed roughly $80 \%$ of pestiferous fruit fly larvae and pupae in certain Hawaiian orchards. Up to $25 \%$ of the Mediterranean fruit fly, Ceratits capitata (Weidemann), larvae in a Guatemalan citrus grove were killed by the fire ant, Solenopsis geminata (F.) (Eskafi and Kolbe 1990; see also Clausen 1940, DeBach 1974, Finnegan 1975, Wong and Wong 1988). Staphylinid beetles are often predators of buried pupae; 7 species are the major cause of Mediterranean fruit fly pupal mortality in parts of Guatemala (Eskafi

\footnotetext{
${ }^{1}$ International Institute of Biological Control, Silwood Park, Ascot Berks., UK, SL5-9PY.

${ }^{2}$ Center for Medical, Agricultural and Veterinary Entomology, USDA-ARS, $1700 \mathrm{SW} 23$ rd Drive, P.O. Box 14565, Gainesville, FL 32604.

${ }^{3}$ Instituto de Ecología, A.C., Apartado Postal 63, 91000, Xalapa, Veracruz, Mexico.
}

and Kolbe 1990). Both staphylinids and carabids consume the pupae of the apple maggot, Rhagoletis pomonella (Walsh) (Boller 1966, Monteith 1971, Allen and Hagley 1990). Deer mice (Peromyscus spp.) ate $34 \%$ of the Anastrepha ludens (Loew) pupae experimentally placed in sites in northern Mexico (Thomas 1993). In agricultural regions, chickens can consume large numbers of pupae (Clausen et al. 1965).

Although predation is often high, environmental differences among sites result in considerable variance in mortality rates. For example, $S$. geminata in a Guatemalan experiment destroyed 6 times as many immature Mediterranean fruit flies as did the same ant species in a Hawaiian study (Wong et al. 1984, Eskafi and Kolbe 1990). Bateman (1976) found differing levels of pupal predation in investigations of fruit fly mortality in 9 different countries. In northern Mexico, season and location have major effects on predation of A. ludens, largely because they influence the abundance of ants and staphylinid beetles (Thomas 1995).

The aims of the study were to contribute information that will help assess the impact of predators on fruit fly populations and to identify some of the factors that have an influence on predation. We first determined for 2 soil types the depths at which pupae of several Mexican Anastrepha spp. are likely to be found. We then compared pupal disappearance at different soil depths in 4 sites that are geographically close but vary in climate, elevation, soil type, and type of natural vegetation. These sites also differ in the species of host fruit and predator species present and management history. 


\section{Materials and Methods}

Study Sites. The study sites were located in the state of Veracruz, Mexico. Four host plant species (1 species per site) were compared: tropical plum (Spondias purpurea L.), jobo (Spondias mombin L.), guava (Psidium guajava L.), and orange (Citrus sinensis Osbek). The sites are described below. The study periods varied with tree species and corresponded to fruiting seasons. Soil compaction at the sites was determined with a Proctor Penetrometer (model EL29-3925, ELE International, Hampstead, England).

Site 1: Tropical Plum. The study area was rows of trees separating a managed mango orchard and an old field and was situated on the outskirts of Apazapan at a latitudeof $19^{\circ} 19^{\prime} \mathrm{N}$, longitude, $96^{\circ} 21^{\prime} \mathrm{W}$, and an altitude of $347 \mathrm{~m}$. The fruiting season of $S$. purpurea coincides with the hottest and driest months (May and June) and during the study period daytime temperatures ranged from 24 to $39^{\circ} \mathrm{C}$ (mean, $32.5^{\circ} \mathrm{C}$ ), with relative humidities of $40-80 \%$ (mean, $53 \% \mathrm{RH}$ ). Surrounding natural vegetation was characteristic of lowland deciduous scrub (see Castillo 1995). During the 1st wk of the study period the horizontal ground cover (both grasses and broadleaved species) in the orchard was $<40 \%$. Later, rains resulted in an increase to $>60 \%$ ground cover. The soil type was a sandy loam. Anastrepha obliqua (Macquart) infested the fruits.

Site 2: Jobo. This site was at the base of a canyon (Ixtla Vieja) $\approx 3 \mathrm{~km}$ from the village of Llano Grande at a latitude $19^{\circ} 22^{\prime} \mathrm{N}$, longitude $96^{\circ} 53^{\prime} \mathrm{W}$, and an altitude of $680 \mathrm{~m}$. The study period (August and September) was climatically warm (mean daytime temperature: $26^{\circ} \mathrm{C}$; range, $21.5-29.5^{\circ} \mathrm{C}$ ) and humid (mean humidity: $67 \%$; range, $54-80 \% \mathrm{RH}$ ). The site was in a semimanaged coffee plantation, shaded by tree canopies with surrounding natural vegetation characteristic of lowland subdeciduous scrub (see Castillo 1995). The ground cover varied within the site from 0 to $70 \%$ and consisted of broad leaved species. The soil was clay loam. A. obliqua infested the fruits.

Site 3: Guava. The study area was a garden orchard within the village of Tejeria at a latitude $19^{\circ} 22^{\prime} \mathrm{N}$ longitude $96^{\circ} 56^{\prime} \mathrm{W}$, and at an altitude of $1,050 \mathrm{~m}$. During the study period (August and September) the daytime temperatures ranged from 22.5 to $32^{\circ} \mathrm{C}$ (mean, $26.9^{\circ} \mathrm{C}$ ) and the humidity ranged from $48-80 \%$ RH (mean, 62\%). The village is within an ecotone between lowland subdeciduous and mountain scrub (see Castillo 1995). Ground cover was $<15 \%$. The soil was clay loam. Anastrepha fraterculus (Wiedemann) and $A$. striata Schiner infested the fruits.

Site 4: Orange. The site was $\approx 200 \mathrm{~m}$ from the village of Tejeria (see above). It was in a managed orchard where the principal crops were oranges and bananas. During the study period (October) the temperatures ranged from 21 to $31^{\circ} \mathrm{C}$ (mean, $28^{\circ} \mathrm{C}$ ). Humidity ranged from 53 to $74 \% \mathrm{RH}$ (mean, $62 \%$ ). Ground cover was $<20 \%$. The soil was clay. Anastrepha ludens (Loew) infested the fruits.

Survey of Natural Pupation Depth. Under the canopies of a tropical plum and a guava tree at sites 1 and 3 the soil (sandy loam and clay loam, respectively) was excavated in layers and examined for fruit fly pupae using the following method. Nine transect lines were marked out in 3 groups of 3. Each line consisted of quadrats (50 by $50 \mathrm{~cm}$ ), 26 per line in tropical plum and 15 in guava. In each quadrat there was a search for pupae at 3 levels, surface, $0-2 \mathrm{~cm}$ and $2-5 \mathrm{~cm}$. In the guava site the $4 \mathrm{th}$ quadrants in each line were sampled at $5-10 \mathrm{~cm}$. After no pupae were found in 18 such quadrats, sampling at this additional depth was abandoned. Soil, sometimes mixed with water to facilitate sifting, was sieved using colanders (pore size, $\approx 1.5 \mathrm{~mm}$ ).

Experimental Manipulation of Pupation Depths. $\mathrm{Pu}$ pal disappearance (presumably caused by predation) was estimated at different soil depths in all 4 sites by placing pupae in the field and then attempting to recover them over time. The species of fruit fly pupae (Anastrepha spp.) used at each site was the most commonly occurring species in that respective site and had been obtained from previous fruit collections. A continuous transect of 10 quadrats ( 200 by $200 \mathrm{~cm}$ ) was set up beneath the canopies of fruiting host plants. Throughout the experiment there were naturally fallen fruits in the study areas. In each quadrat, 30 pupae were positioned, 10 at each of the following 3 levels: soil surface, $2.5 \mathrm{~cm}$ depth, $5 \mathrm{~cm}$ depth. The position of each pupa was recorded with an ink mark on string stretched across the ground surface. On each of the following $10 \mathrm{~d}, 1$ randomly chosen quadrat was sampled. Pupation periods for all the species examined range from 10 to $>20 \mathrm{~d}$, depending on environmental conditions (Aluja 1993); thus, pupae were exposed for approximately the minimum developmental period. The line of quadrats was divided into 3 blocks to account for possible environmental gradients, and the 3 blocks and the quadrats within each block were then sampled randomly. (Note that the 10 quadrats could not be equally divided into 3 blocks, and that certain blocks contained different portions of the same quadrat.) The soil was sieved to locate surviving pupae. When soil wetness impeded sieving the soil was washed away in a bucket of water to reveal the pupae. In addition, the number of potential surface-dwelling predators (usually ants) in each quadrat was counted each day. This was an attempt to investigate whether activity was higher in any particular quadrat. The number of fallen fruit was also noted because this was assumed to constitute an attractive stimulus to ground predators. Pitfall traps, $\approx 15 \mathrm{~cm}$ in diameter, were placed in Llano Grande and Tejeria during the study period of August and September 1994, and in Apazapan during May 1994. The trapped ants were counted and identified to genus and the relative contributions of the different genera to the ant guilds were calculated.

Data Analysis. Data concerning the disappearance of pupae were analyzed using GLIM (generalised linear interactive models; NAG, Downer's Grove, IL). Time was treated as a continuous variable. Depth and site were treated as factors. The proportion of pupae found on a given date was analyzed assuming binomial errors and a logit like function. To correct for overdispersion, $F$ tests were used (estimated heterogeneity factor $=1.6$ ) . 
Table 1. F values for pupal disappearance when data from all sites is combined

\begin{tabular}{lccc}
\hline \multicolumn{1}{c}{ All sites } & $F$ value & df, error & Significance \\
\hline Time & 111.45 & 1,108 & $* * *$ \\
Depth & 90.06 & 2,108 & $* * *$ \\
Site & 25.7 & 3,108 & $* * *$ \\
Time $\times$ Depth & 19.57 & 2,108 & $* *$ \\
Time $\times$ Site & 6.24 & 2,108 & $* *$ \\
Depth $\times$ Site & 3.82 & 6,108 & $* *$ \\
Time $\times$ Depth $\times$ Site & 6.74 & 6,108 & $* * *$ \\
\hline
\end{tabular}

$F$ values indicate the importance of time, depth, and site in emplaning the variance in pupal disappearance. The explanatory variables are also given

\section{Results}

Survey of Natural Pupation Depth. Excavations in the sandy-loam soils under tropical plum at the Apazapan site uncovered 81 pupae of $A$. obliqua. Only 1 pupa occurred at a depth $>5 \mathrm{~cm}$ and none were found on the surface. There were 45 pupae found at depths of up to 2 $\mathrm{cm}$ and 35 at $2-5 \mathrm{~cm}$. In the clay-loam soil of the guava site, 116 immatures, larvae and pupae, were collected. Ten of 11 larvae and 1 pupa were on the surface. No pupae were at a depth of $>2 \mathrm{~cm}$.

Experimental Manipulation of Pupation Depth. There was a significant 3-way interaction among the variables time, depth, and site, indicating that the proportion of pupae disappearing differed among sites and depths and over time (Table 1). Fig. 1 shows that at all sites pupae disappeared most rapidly from the surface. The guava site at Tejeria is notable for the immediate loss of all surface pupae over the first $24 \mathrm{~h}$. In the Apazapan-plum site this occurred over $3 \mathrm{~d}$. The other 2 sites showed a more gradual decline. In the Llano Grande-jobo site pupae persisted on the surface to the 5 th $\mathrm{d}$, and in the orange site at Tejeria until the final day of sampling.

The buried pupae declined most rapidly in the Apazapan-plum and more gradually in the Llano Grande-jobo site and in the orange site at Tejeria. In the guava site in Tejeria there was very little loss over the 1 st $6 \mathrm{~d}$ and even on the last day of sampling $70 \%$ of the pupae remained.

Soil Compaction. The soil compaction (pounds/ square inch required to penetrate a sample) in the vicinities of the experimental sites are as follows: Apazapan, $15 \mathrm{~kg} / \mathrm{sq} \mathrm{cm}$; Tejerias, $15.8 \mathrm{~kg} / \mathrm{sq} \mathrm{cm}$; Llano Grande, $20.2 \mathrm{~kg} / \mathrm{sq} \mathrm{cm}$. The lowest compaction occurs in a sandy loam soil, and the highest in a clay loam containing a large proportion of organic material. The intermediate value occurred in a well drained clay loam soil (see previous descriptions of sites).

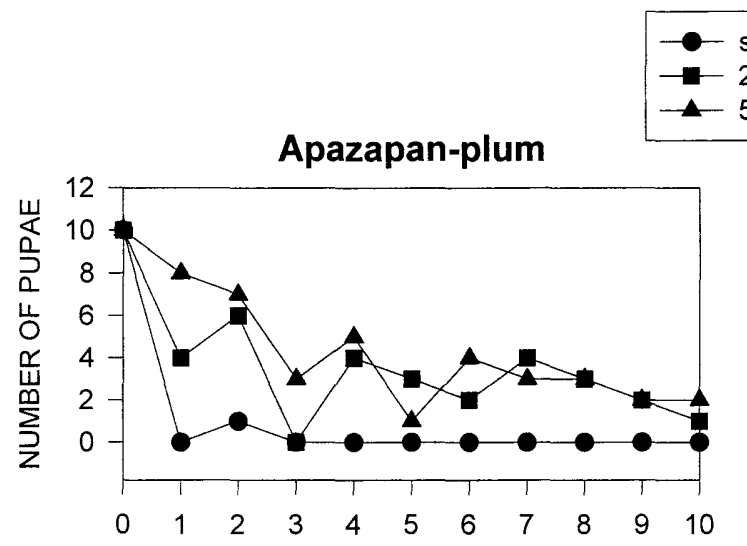

\section{surface \\ $2.5 \mathrm{~cm}$. depth \\ $5 \mathrm{~cm}$. depth}

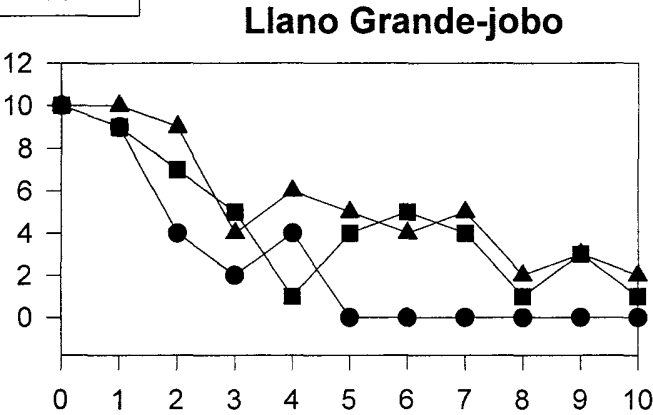

Tejeria-guava

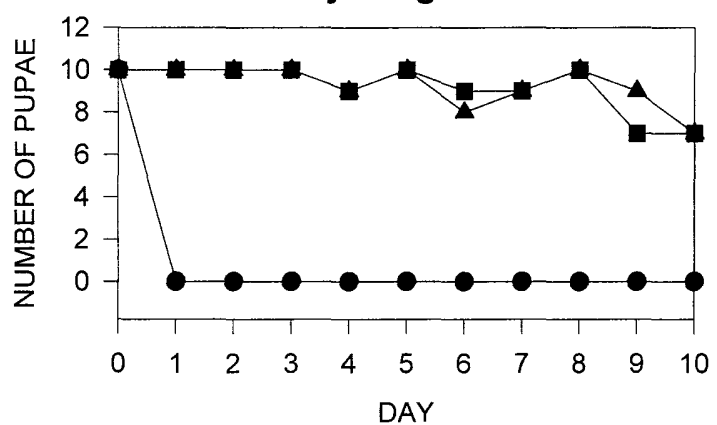

Tejeria-orange

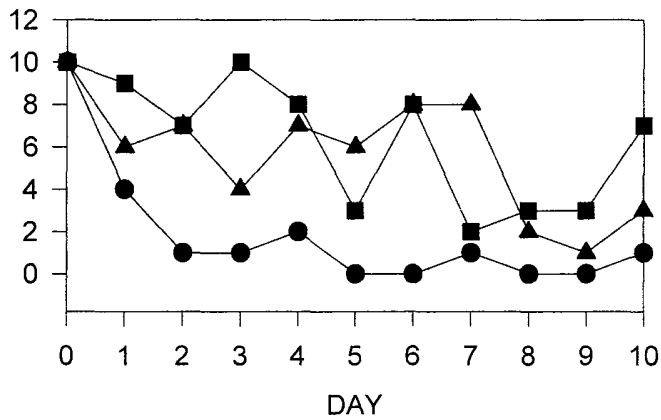

Fig. 1. Pupal disappearance. For each site, pupal disappearance against time (measured in days after placement of the pupae) for the 3 levels (i.e., surface, $2.5 \mathrm{~cm}, 5 \mathrm{~cm}$ ). 
Table 2. Proportions of individuals collected from various ant genera present in the sites in or near Apazapan, Llano Grande, and Tejeria at the time of the studies

\begin{tabular}{lccc}
\hline \hline & Apazapan & $\begin{array}{c}\text { Llano } \\
\text { Grande }\end{array}$ & Tejeria \\
\hline Apterostigma & - & 0.02 & - \\
Atta & 0.07 & 0.04 & - \\
Brachymyrmex & 0.01 & 0.07 & 0.08 \\
Campnotus & 0.06 & - & - \\
Cardiocondyla & 0.01 & - & - \\
Crematogaster & - & - & - \\
Gnaptogenys & - & 0.02 & - \\
Dorymyrmex & 0.30 & - & - \\
Macromisha & - & - & 0.02 \\
Monomorium & - & 0.05 & - \\
Mycocepurus & - & 0.02 & - \\
Pachycondola & - & 0.02 & - \\
Paratrechina & - & 0.26 & 0.08 \\
Pheidole & 0.20 & - & - \\
Pogonomyrmex & 0.10 & - & - \\
Pseudomyrmex & 0.01 & 0.42 & 0.83 \\
Solenopsis & 0.26 & 0.02 & - \\
Trachymyrmex & 0.01 & 0.04 & - \\
Wasmannia & - & &
\end{tabular}

Predator Activity. There were no differences in predator composition among quadrats within a site. Ants were the most frequently sampled (Table 2), and at the Apazapan-plum site and at the orange site at Tejeria they were observed removing pupae. Staphylinid beetles were also collected in the Llano Grande-jobo site and the orange site at Tejeria.

The number of fruit per quadrat increased toward the end of the sampling period. Although there was a marked variance in numbers of fruits between quadrats, there was no correlation with predaceous insect activity.

\section{Discussion}

Within all the sites, pupae on the surface were lost more rapidly than the buried pupae. This was probably a result of greater and more uniform ant activity on the surface. Activity below ground may be more localized and confined to nests and pathways. In the guava site at Tejeria the rapid removal of pupae during the first $24 \mathrm{~h}$ was likely the result of chicken predation. Shortly after the pupae had been placed, several of the birds were seen scratching and pecking in the vicinity.

The other feature common to all sites was that the disappearance of the buried pupae was independent of the depth at which they had been placed. This implies that there is no advantage for the larvae to burrow deeper than $2.5 \mathrm{~cm}$, which would be a costly exercise in terms of energy expense. Such expenses presumably account for the propensity of $A$. fraterculus larvae to dig more deeply in less compacted soil (Bressan and Teles 1990, Salles and Carvalho 1993). This homogeneity of mortality in buried pupae is consistent with the absence of pupae in one of the natural sites at depths $>2 \mathrm{~cm}$ and their rarity in the other at depths $>5 \mathrm{~cm}$.

There was considerable variability in mortality of buried pupae among sites. In Apazapan (A. obliqua in tropical plum) and Llano Grande (A. obliqua in jobo), only
$15 \%$ of buried pupae remained after $10 \mathrm{~d}$; whereas in Tejeria (A. ludens in guava), $70 \%$ of the buried pupae remained on the final day of sampling. The differences in pupal disappearance might be a result of differences in predator species, soil texture, and surrounding vegetation. At Apazapan and Llano Grande, where buried pupae suffered high mortalities, Pheidole spp. were among the more common ants. These ants were relatively less common at the Tejeria site where buried pupae had the highest survival. Solenopsis gemminata, a pugnacious and efficient predator (e.g., Wilson 1975, Feener 1987), was a prominent species in all the sites, but was particularly common at the Tejeria site with the high levels of survival for underground pupae. These patterns of pupal disappearance and ant fauna composition suggest that an experimental comparison of the abilities of S. geminata and Pheidole spp. to forage under the soil might be warranted.

In addition to having a relatively low diversity of ant species and low pupal mortality, the Tejeria site had the least ground cover $(<20 \%)$. Perhaps these factors are related (i.e., a simple habitat offers fewer opportunities for various species of predators and as a result pupae in certain places, such as underground, are less vulnerable to predation). The most common ant at the Tejeria site, S. geminata, is often found in disturbed habitats (e.g., Risch and Carroll 1982).

Soil textures may be important in determining the ease of movement of subterranean predators (e.g., Johnson 1992). The dry, sandy soil in Apazapan had the lowest compaction value. Pupae disappeared here at the greatest rate, and the looseness of the soil could have facilitated burrowing by predators. At the other extreme of buried pupal mortality, under guava in Tejeria, the very slow disappearance of buried pupae may have been a result of the clay-loam soil with its finer particle size and less interparticle space. It should be noted that experimentally burying pupae might have changed the compaction of the soil relative to the surrounding habitat. However, the natural burrowing of the larvae toward its pupation site could also loosen the soil and perhaps provide access for predators.

In summary, as in previous studies, we found considerable differences among locations in the survival of tephritid pupae. However, this study emphasizes the importance of microhabitat on the rate of pupal disappearance, presumably through predation. All sites were relatively close to each other, although they differed in features such as fruit tree species and ground-covering vegetation. In addition, we found that the soil characteristics of the microhabitat are likely to affect pupal survival by influencing the depth to which larvae burrow to pupate and the likelihood that predators will later discover buried pupae.

Our findings and observations suggest that it may be possible to devise tephritid control programs that enhance predation through cultural techniques. For example, in small, low-impact orchards, pigs might be used to remove fallen fruits, chickens to consume pupae on the surface, and insects to attack buried pupae. Insect predators might be encouraged by loosening the surface of the soil within groves. This could increase ant penetration and movement, expose pupae to the surface where 
the mortality risks are greater, and encourage the establishment of S. gemminata, an ant that colonizes disturbed environments (Risch 1981, Risch and Carroll 1982). When loosening soil, care should be taken to not damage tree roots. This type of injury may allow the entry of pathogens into the plant.

\section{Acknowledgments}

The grove owners who kindly allowed us use of their lands were Doña Iris Quinto, Doña Leticia Lagunes, Doña Trinidad Alvarez, Don Pedro Córdova, Don Othón Alvarez, and Don Faustino Cabrera. Technical support was provided by Enrique Piedra, Andrea Birke, Isabel Jácome, Jaime Piñero, Alejandro Vasquez, Maurilio López and Cesar Ruiz. Miguel Equihua, Mark Rees and Mick Crawley gave welcome statistical advice. Howard Frank, Michael Hennessy, Hefin Jones, Mike Bonsall, and Donald Thomas helped with the manuscript. Lloyd Davis identified the ants captured on the sites.We thank Jesus Reyes Flores (Campaña Nacional Contra las Moscas de la Frutas Dirección General de Sanidad Vegetal- Secretar'a de Agricultura, Ganader'a y Desarrollo Rural) for encouragement and inviting us to obtain the funds for this project. Funds were provided by the Campaña Nacional Contra las Moscas de la Fruta (SAGDR-IICA), the Comision National para el Conocimiento y Uso de la Biodiversidad (CONABIO), the Consejo National de Ciencia y Tecnologia, Sistema de Investigation del Golfo de Mexico (CONACyT-SIGOLFO) project \#01-003, and the USDA-OICD. The Royal Society of London, The British Council, CONACYT and Academia de la Investigacíon Cientifíca provided a fellowship for P.J.H. and paid her travel costs.

\section{References Cited}

Allen, W., and E. Hagley. 1990. Epigeal arthropods as predators of mature larvae and pupae of the apple maggot (Diptera: Tephritidae). Environ. Entomol. 19: 309-312.

Aluja, M. 1993. Bionomics and management of Anastrepha. Annu. Rev. Entomol. 39: 155-178.

Aluja, M., and P. Liedo [eds.]. 1993. Fruit flies: biology and management. Springer, New York.

Bateman, M. 1976. Fruit flies, pp. 11-49. In V. Delucchi [eds.], Studies in biological control. Cambridge University Press, Cambridge.

Boller, E. 1966. Der Einfluss natürlicher Reduktionfaktoren auf die Kirschenfliege Rhagoletis cerasi L. in der Nordwestschweiz, unter besconderer Berïcksichtigung des Puppenstadiums. Schweiz. Landwirtsch. Forsch. 5: 154210.

Bressan, S., and M. C. Teles. 1990. Profundidae de Pupação de Anastrepha obliqua (MacQuart, 1835) (Diptera: Tephritidae) em tres substratos. An. Soc. Entomol. Brasil 19: 471-479.

Castillo, C. G. 1995. Ecologia del paisate del municipo de Jalcomulco, Veracruz. Tesis de Maestria, Faculdad de Ciencias, UNAM, Mexico City, Mexico.

Clausen, C. P. 1940. Entomophagous insects. Mcgraw Hill, New York.

Clausen, C., D. Clancy and Q. Chock. 1965. Biological control of the oriental fruit fly (Dacus dorsalis Hendel) and other fruit flies in Hawaii. U.S. Dep. Agric.-ARS Tech. Bull. 1322.
DeBach, P. 1974. Biological control by natural enemies. Cambridge University Press, Cambridge.

Eskafi, F. M, and M. M. Kolbe. 1990. Predation on larval and pupal Ceratitis capitata (Diptera: Tephritidae) by the ant Solenopsis geminata (Hymenoptera: Formicidae) and other predators in Guatemala. Environ. Entomol. 19: 148 153.

Feener, D. H. 1987. Response of Pheidole morrisi to two species of enemy ants, and a general model of defense behavior in Pheidole (Hymenoptera: Formicidae). J. Kans. Entomol. Soc. 60:569-5755.

Finnegan, R. J. 1975. Introduction of a predaceous red wood ant Formica lugubris (Hymenoptera: Formicae) from Italy to Eastern Canada. Can. Entomol. 107: 1271-1274.

Johnson, R. A. 1992. Soil texture as an influence on the distribution of the desert seed-harvester ants Pogonomyrmex rugosus and Messor pengaudei. Oecologia (Berl.) 89: $118-124$.

Monteith, L. 1971. Crickets as predators of the apple maggot, Rhagoletis pomonella (Diptera: Tephritidae). Can. Entomol. 103: 52-58.

Pemberton, C., and H. Willard. 1918. A contribution to the biology of fruit fly parasites in Hawaii. J. Agric. Res. 15: $419-465$.

Risch, S. J. 1981. Ants as important predators of rootworm eggs in the Neotropics. J. Econ. Entomol. 74: 88-90.

Risch, S. J., and C. R. Carroll. 1982. The ecological role of ants in two Mexican agroecosystems. Oecologia (Berl.) 55: $114-119$

Salles, L.A.B. and F.L.C. Carvalho. 1993. Profunidade da localização da puparia de Anastrepha fraterculus (Wied.) (Diptera: Tephritidae) em differentes condições do solo. An. Soc. Entomol. Brasil. 22:299-305.

Silvestri, F. 1914. Report of an expedition to Africa in search of natural enemies of fruit flies (Trypaneidae). Terr. Hawaii Bd. Agric For. Bull. 3.

Sivinski, J. 1996. The past and potential of fruit fly biological control, pp. 369-375. In B. McPheron and G. Steck [eds. ], Fruit fly pests. St. Lucie Press, Delray Beach, FL.

Thomas, D. B. 1993. Survivorship of the pupal stages of the Mexican fruit fly Anastrepha ludens (Loew) (Diptera: Tephritidae) in an agricultural and a nonagricultural situation. J. Entomol. Sci. 28: 350-362.

Thomas, D. B. 1995. Predation on the soil inhabiting stages of the Mexican fruit fly. Southwest. Entomol. 2: 61-71.

Wilson, E. O. 1975. Enemy specification in the alarm-recruitment system of an ant. Science (Wash. D.C.). 190 $798-800$.

Wong, T.T.Y., D. O. McInnis, J. I. Nishimoto, A. K. Ota, and V.S.C. Chang. 1984. Predation of the Mediterranean fruit fly (Diptera: Tephritidae) by the argentine ant (Hymenoptera:Formicidae) in Hawaii. J. Econ. Entomol. 77: $1454-1458$.

Wong, M. A., and T.T.Y. Wong. 1988. Predation of the Mediterranean fruit fly and the oriental fruit fly (Diptera: Tephritidae) by the fire ant (Hymenoptera: Formicidae) in Hawaii. Proc. Hawaii. Entomol. Soc. 28: 169-177. 